\title{
ANALISIS KEPUASAN SISWA TERHADAP LAYANAN DI MAN TAMBAK BERAS JOMBANG
}

\author{
Mukhtar $^{(1)}$, Edy Sulistiyawan ${ }^{(2)}$ \\ ${ }^{(1),(2)}$ Fakultas Matematika dan Ilmu Pengetahuan Alam Universitas PGRI Adi Buana Surabaya
}

\begin{abstract}
ABSTRAK
Setiap sekolah mempunyai cara yang tersendiri untuk memberikan layanan kepada siswa untuk mengembangkan sekolah tersebut menjadi lebih baik. Tujuan dari penelitian ini adalah untuk mengetahui variabel-variabel layanan apa sajakah yang berpengaruh signifikan terhadap kepuasan siswa. Prosedur dalam penelitian ini yaitu, pertama membagi kuisioner kepada 117 siswa untuk 39 kelas X dan XI. Dari data hasil kuisioner tersebut kemudian dilakukan analisis. Analisis yang digunakan dalam penelitian ini adalah menggunakan analisis regresi. Dari hasil analisis regresi didapatkan untuk uji F, variabel reliability (X1), responsiveness (X2), assurance (X3), empathy (X4), dan tangible (X5) mempunyai pengaruh yang signifikan secara bersama-sama terhadap variabel kepuasan siswa terhadap layanan sekolah. Pada model regresi variabel tangible paling berpengaruh terhadap kepuasan siswa terhadap layan sekolah, oleh sebab itu variabel tangible (X5) adalah variabel yang lebih ditingkatkan dibandingkan variabel X1, X2, X3 dan X5.
\end{abstract}

Kata kunci : Analisis regresi, Kepuasan siswa, reliability, responsiveness, assurance, empathy dan tangible.

\section{PENDAHULUAN}

Di zaman sekarang ini pendidikan adalah sesuatu yang sangat penting bagi manusia. Dengan pendidikan yang baik manusia akan bisa meningkatkan derajat maupun perekonomian. Baik buruknya suatu negara juga menentukan kesejahteraan negara tersebut. Dengan sistem pendidikan yang baik suatu negara akan menghasilkan sumber daya manusia (SDM) yang berkualitas yang bisa memajukan negara tersebut. Di Indonesia system pendidikan sudah banyak berubah. Banyak usaha yang dilakukan pemerintah untuk meningkatkan kualitas pendidikan diantaranya memberikan bantuan dana BOS di sekolah-sekolah, merubah sistem ujian kelulusan sekolah, memberikan bantuan dana untuk pembangunan sekolah ke sekolahsekolah, adanya sertifikasi guru, dan lain-lain.

Saat ini banyak berdiri sekolah-sekolah baik dari tingkat SD maupun SMA baik negeri maupun swasta. Dengan banyaknya sekolah pemerintah maupun suatu yayasan pendidikan tentunya bertujuan untuk memberikan sesuatu kepada masyarakat yaitu dengan pemerataan pendidikan. Namun yang terjadi kadang tidak sesuai harapan. Ada sebagian sekolah menetapkan biaya yang terlampau mahal sehingga hanya kalangan tertentu saja yang bisa bersekolah di sekolah tersebut. Selain itu dari segi biaya yang mahal terkadang tidak ditunjang dengan layanan yang memadai.

Masyarakat tentunya faham bagaimana memilihkan sekolah yang baik untuk putra-putri mereka. Alasan para orang memilih suatu sekolah untuk putra-putri mereka antara lain dari segi peringkat sekolah, kemampuan guru, fasilitas yang memadai, biaya dan lain-lain. Dengan sekolah yang berkualitas tentunya putra-putri mereka juga akan nyaman dalam kegiatan belajar-mengajar.

MAN Tambakberas Jombang merupakan Sekolah Negeri setingkat SMA yang memiliki kualitas baik. Hal itu terbukti dengan banyaknya prestasi yang ditorehkan oleh siswa-siswi MAN Tambakberas Jombang dengan menjuarai beberapa olimpiade. Selain itu MAN Tambakberas Jombang juga dikenal mempunyai managemen pengelolaan sekolah yang baik. MAN Tambakberas Jombang juga mempunyai siswa-siswi yang cukup banyak yang terdiri dari cukup banyak kelas juga.

\section{METODE PENELITIAN}

Adapun populasi dan sampel yang digunakan pada penelitian ini adalah untuk populasinya siswa MAN Tambakberas Jombang dari kelas X dan XI. Sedangkan sampelnya sendiri diambil 3 siswa dari 39 kelas yang ada di MAN Tambakberas Jombang, sehingga jumlah $n$ sebesar 117 siswa.

Sedangkan untuk metode yang digunakan dalam penelitian ini adalah dengan menggunakan metode angket atau kuisioner yang mana dalam angket terdapat beberapa pertanyaan yang berkaitan dengan kepuasan siswa (terdapat beberapa variabel). Analisis yang digunakan dalam penelitian ini adalah dengan menggunakan analisis regresi. Dari hasil analisis regresi tersebut maka didapatkan variabel mana saja yang berpengaruh signifikan terhadap kepuasan siswa.

\section{HASIL DAN PEMBAHASAN}

3.1 Deskriptif Data 
Pada penyebaran kuesioner karakteristik yang diukur yaitu berdasarkan jenis kelamin, usia, dan asal daerah. Pada penyebaran kuesioner ini dilakukan pada seluruh siswa kelas X dan XI MAN Tambakberas Jombang. Mahasiswa Teknik Mesin Universitas di Malang yang menjadi responden pada penelitian ini yaitu angkatan Tahun 2014-2015 yang berjumlah 117 siswa.

Data usia responden dalam penelitian ini ditunjukkan pada diagram lingkaran pada gambar 3.1:

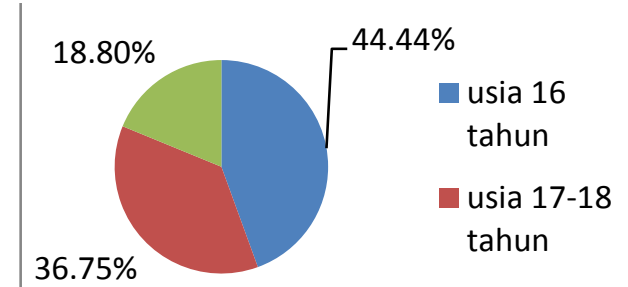

Gambar 3.1 Persentase responden berdasarkan usia

Pada Gambar 3.1 terlihat persentase umur responden terbanyak yaitu:

1. 16 Tahun sebanyak $44,44 \%$

2. $17-18$ Tahun sebanyak $36,75 \%$

3. $14-15$ Tahun sebanyak $18,80 \%$

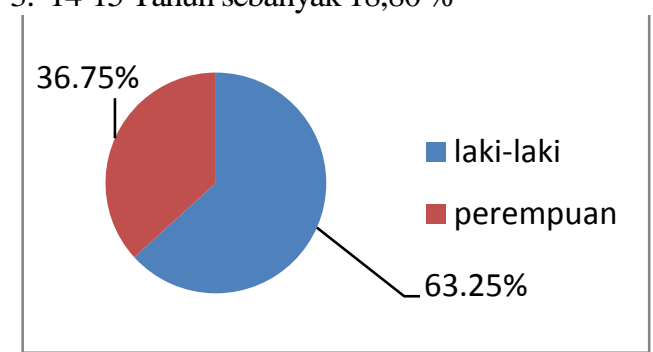

Gambar 3.2 Persentase responden berdasarkan jenis kelamin

Berdasarkan diagram lingkaran pada gambar 3.2 menunjukkan $63,25 \%$ responden adalah perempuan dan $36,75 \%$ adalah laki-laki.

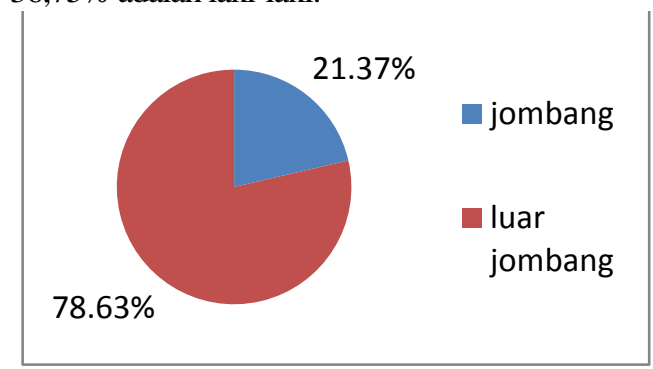

Gambar 3.3 Persentase responden berdasarkan asal daerah

Untuk data tempat tinggal dapat diketahui bahwa siswa MAN Tambakberas Jombang terbanyak merupakan pendatang atau warga dari luar kota Jombang yaitu sebesar 78,63\%, sedangkan siswa yang asli tinggal di jombang sebesar $21,37 \%$.

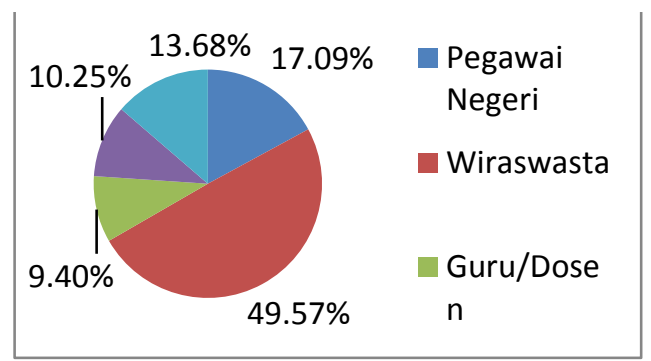

Gambar 3.4 Persentase responden berdasarkan pekerjaan orang tua

Pada Gambar 3.1 terlihat persentase pekerjaan orang tua responden terbanyak yaitu:

Wiraswasta sebanyak 49,57\% ; Pegawai Negeri sebanyak 17,09\%; Lain-lain sebanyak 13,68\%

Pegawai Swasta sebanyak 10,25\% ; Guru/Dosen sebanyak $9,40 \%$

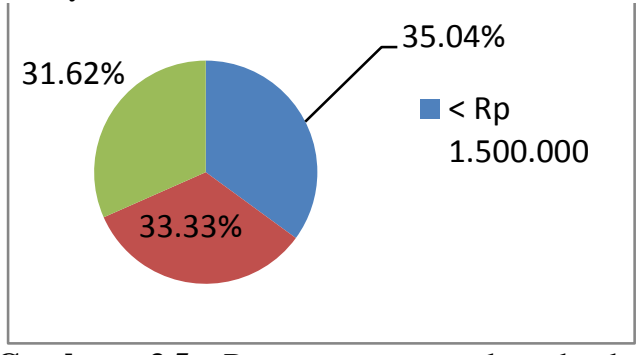

Gambar 3.5 Persentase responden berdasarkan penghasilan orang tua

Sedangkan untuk penghasilan orang tua menunjukkan bahwa 35,04\% memiliki orang tua dengan penghasilan Rp 1.500.000-Rp 2.500.000, kemudian 33,33\% dengan penghasilan orang tua di atas dari Rp 2.500.000, dan $31,62 \%$ dengan penghasilan $31,62 \%$.

\subsection{Analisis Regresi Berganda \\ a. Uji Validitas}

Dari uji validitas setiap variabel X1, X2, X3, X4, X5 dan Y dengan menggunakan software SPSS didapatkan hasil sebagai berikut:

Reliability (X1)

Masing-masing variabel reliability (X1) memiliki nilai $\mathrm{R}$ hitung untuk X11, X12 dan X13 berturut-turut sebesar 0,326, 0,449 dan 0,360. Sedangkan untuk R Tabel(115) sebesar 0,1816. Karena nilai R hitung > RTabel(n-2) dengan demikian masing-masing item pernyataan dari variabel Penelitian pada masing-masing item pertanyaan dinyatakan valid dan selanjutnya dapat digunakan dalam penelitian.

Responsiveness (X2)

Masing-masing variabel responsiveness (X2) memiliki nilai R hitung untuk X21, X22 dan X23 berturut-turut sebesar 0,369, 0,342 dan 0,396. Sedangkan untuk R Tabel(115) sebesar 0,1816. Karena nilai R hitung > RTabel(n-2) dengan demikian masing-masing item pernyataan dari variabel Penelitian pada masing-masing item pertanyaan dinyatakan valid dan selanjutnya dapat digunakan dalam penelitian. 
Assurance (X3)

Masing-masing variabel assurance (X3) memiliki nilai $\mathrm{R}$ hitung untuk X31, X32 dan X33 berturut-turut sebesar 0,473, 0,575 dan 0,299. Sedangkan untuk R Tabel(115) sebesar 0,1816. Karena nilai R hitung > RTabel(n-2) dengan demikian masing-masing item pernyataan dari variabel Penelitian pada masing-masing item pertanyaan dinyatakan valid dan selanjutnya dapat digunakan dalam penelitian.

\section{Empathy (X4)}

Masing-masing variabel empathy (X4) memiliki nilai $\mathrm{R}$ hitung untuk X41, X42 dan X43 berturut-turut sebesar 0,379, 0,378 dan 0,348. Sedangkan untuk R Tabel(115) sebesar 0,1816. Karena nilai R hitung > RTabel(n-2) dengan demikian masing-masing item pernyataan dari variabel Penelitian pada masing-masing item pertanyaan dinyatakan valid dan selanjutnya dapat digunakan dalam penelitian.

Tangible (X5)

Masing-masing variabel tangible (X5) memiliki nilai $\mathrm{R}$ hitung untuk X51, X52 dan X53 berturut-turut sebesar 0,444, 0,757 dan 0,784. Sedangkan untuk R Tabel(115) sebesar 0,1816. Karena nilai R hitung > RTabel(n-2) dengan demikian masing-masing item pernyataan dari variabel Penelitian pada masing-masing item pertanyaan dinyatakan valid dan selanjutnya dapat digunakan dalam penelitian.

Kepuasan (Y)

Masing-masing variabel Kepuasan (Y) memiliki nilai $\mathrm{R}$ hitung untuk Y11, Y12, Y13, Y14 dan Y15 berturutturut sebesar 0,643, 0,729, 0,549, 0,508 dan 0,556. Sedangkan untuk R Tabel(115) sebesar 0,1816. Karena nilai R hitung > RTabel(n-2) dengan demikian masingmasing item pernyataan dari variabel Penelitian pada masing-masing item pertanyaan dinyatakan valid dan selanjutnya dapat digunakan dalam penelitian.

\section{b. Uji Reliabilitas}

Hasil uji reliability ditunjukkan pada tabel 3.1

Tabel 3.1 Validitas tiap variabel yang menyatkan kepuasan

\begin{tabular}{|l|r|l|}
\hline Variabel & \multicolumn{1}{|l|}{ Alpha } & Keterangan \\
\hline Reliability & 0.6 & Realibel \\
\hline Responsiveness & 0.6 & Realibel \\
\hline Assurance & 0.633 & Realibel \\
\hline Empathy & 0.6 & Realibel \\
\hline Tangible & 0.799 & Realibel \\
\hline Satisfaction & 0.803 & Realibel \\
\hline
\end{tabular}

Pada tabel 3.1 menunjukkan bahwa nilai reliabilitas konsistensi internal, untuk koefisien alpha masingmasing variabel dalam setiap variabel dinyatakan reliabel karena lebih besar dari 0,6. Dengan demikian item pengukuran pada masing-masing variabel dinyatakan reliabel dan selanjutnya dapat digunakan dalam penelitian.

\section{c. Uji Serentak}

Dari Uji serentak didapatkan F hitung sebesar 24,478 dengan angka signifikansi ( $\mathrm{P}$ value) sebesar 0,000. Dengan tingkat signifikansi 95\% $(\alpha=0,05)$. Angka signifikansi ( $\mathrm{P}$ value) sebesar $0,000<0,05$. Atas dasar perbandingan tersebut, maka $\mathrm{H} 0$ ditolak atau berarti variabel reliability (X1), responsiveness (X2), assurance (X3), empathy (X4), dan tangible (X5) mempunyai pengaruh yang signifikan secara bersama-sama terhadap variabel kepuasan siswa terhadap layanan sekolah.

\section{d. Uji Koefisien Determinasi}

Dari uji koefisien determinasi nilai didapatkan Adjusted $\mathrm{R}^{2}$ adalah sebesar 0,503 . Hal ini dapat diartikan bahwa variabel independent (reliability (X1), responsiveness (X2), assurance (X3), empathy (X4), dan tangible (X5)) dapat menjelaskan variabel dependent (kepuasan siswa terhadap layanan) sebesar 50\%, sedangkan sisanya diterangkan oleh faktor lain yang tidak diteliti.

\section{e. Uji Parsial}

Dari uji parsial didapatkan hasil sebagai berikut:

Tabel 3.2 Hasil Uji parsial

\begin{tabular}{|l|l|}
\hline \multirow{2}{*}{ Variabel } & Hasil Uji \\
\cline { 2 - 2 } & Signifikansi \\
\hline Reliability & -0.721 \\
\hline Responsiveness & 2.316 \\
\hline Assurance & 2.11 \\
\hline Empathy & 0.646 \\
\hline Tangible & 5.648 \\
\hline
\end{tabular}

Pada tabel 3.2 menunjukkan variabel reliability dengan tingkat signifikansi 95\% $(\alpha=0,05)$. Angka signifikansi ( $P$ Value) pada variabel bukti langsung sebesar $0,721<0,05$. Atas dasar perbandingan tersebut, maka variabel reliability mempunyai pengaruh yang signifikan terhadap variabel kepuasan siswa. Sedangkan variabel Responsiveness, Assurance, Empathy dan Tangible tidak mempunyai pengaruh yang signifikan terhadap variabel kepuasan siswa karena Sigifikansinya > 0,05.

\section{f. Model Analisis Regresi Linier Berganda}

Model yang didapat dari analisis regresi adalah sebagai berikut:

$\mathrm{Y}^{\wedge}=2.27$

$0.111 X \_1+0.379 X \_2+0.363 X \_3+0.100 X \_4+0.680 X \_5$

Dari model regresi ini nampak bahwa satu variabel layanan mempunyai hubungan yang negatif dengan penjualan, yaitu : Reliability (X1).

Persamaan regresi dengan memasukkan kelima variabel tersebut menghasilkan $\mathrm{R}^{2}$ cukup tinggi yaitu : $5.24 \%$. Sehingga dapat diartikan bahwa sebesar $5.24 \%$ keragaman/ variasi dari kepuasan dapat dijelaskan oleh masuknya kelima variabel dalam model.

\subsection{Uji Asumsi}

\section{a. Uji Multikolinier}

Hasil dari uji asumsi multikolinearitas, nilai VIF variable variabel reliability (X1), responsiveness (X2), assurance 
(X3), empathy (X4), dan tangible (X5) berturut-turut $(1,368 ; 1,526 ; 1,691 ; 1,560$; dan 1,739) < 10, sehingga dapat disimpulkan tidak ada multikolinearitas antara kelima variabel independent tersebut.

\section{b. Uji Normalitas}

3.6

Dari uji normalitas didapatkan grafik pada gambar

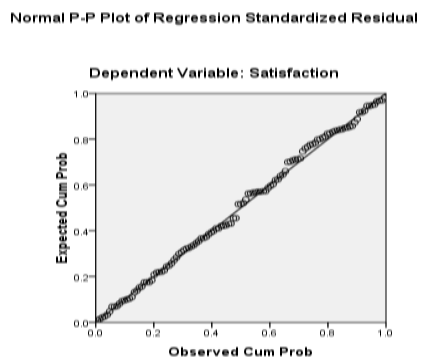

Gambar 3.6 Hasil uji normalitas dari error Karena plot mendekati garis diagonal, maka dapat disimpulkan error memenuhi asumsi normalitas. Uji normalitas error juga dapat dilakukan dengan uji Kolmogorov-Smirnov.

Dari uji uji Kolmogorov-Smirnov nilai Z berturutturut adalah 1,$448 ; 2,031 ; 2,002 ; 1,528 ; 1,836 ; 1,116$ yang berart Zhitung $>0,05$, artinya data terdistribusi secara normal.

\section{c. Uji Heteroskedastisitas dan Autokorelasi}

Hasil plot berikut pada Gambar 3.7 menunjukkan tidak ada pola yang jelas atau berpola acak, sehingga dapat disimpulkan tidak terjadi heteroskedastisitas atau ragam galat konstan dan galat bersifat acak atau tidak ada autokorelasi .

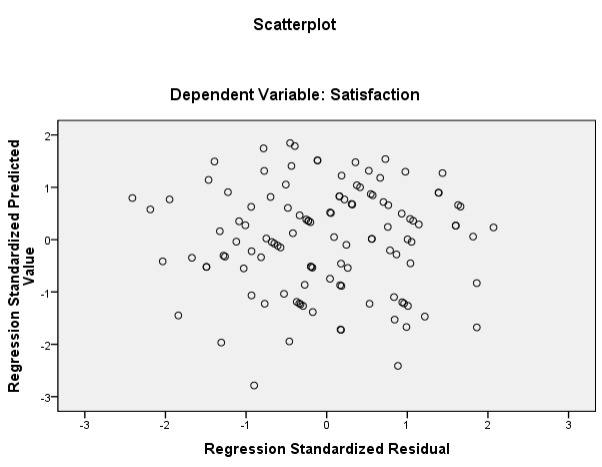

Gambar 3.7 Scatterplot variabel kepuasan

Kesimpulan

Dari penelitian yang dilakukan didapatkan kesimpulan sebagai berikut:

Dari pengujian $\mathrm{F}$, didapatkan $\mathrm{F}$ hitung sebesar 24,478 dengan angka signifikansi ( $\mathrm{P}$ value) sebesar 0,000. Dengan tingkat signifikansi 95\% $(\alpha=0,05)$. Angka signifikansi (P value) sebesar $0,000<0,05$. Atas dasar perbandingan tersebut, maka $\mathrm{H} 0$ ditolak atau berarti variabel reliability $(\mathrm{X} 1)$, responsiveness $(\mathrm{X} 2)$, assurance (X3), empathy (X4), dan tangible (X5) mempunyai pengaruh yang signifikan secara bersamasama terhadap variabel kepuasan siswa terhadap layanan sekolah.

Model yang didapat dari analisis regresi adalah sebagai berikut:

$\mathrm{Y}=2.27$ -

$0.111 X \_1+0.379 X \_2+0.363 X \_3+0.100 X \_4+0.680 X \_5$

Dari model regresi ini nampak bahwa satu variabel layanan mempunyai hubungan yang negatif dengan penjualan, yaitu : Reliability (X1).

Persamaan regresi dengan memasukkan kelima variabel tersebut menghasilkan $\mathrm{R}^{2}$ cukup tinggi yaitu : $5.24 \%$. Sehingga dapat diartikan bahwa sebesar $5.24 \%$ keragaman/ variasi dari kepuasan dapat dijelaskan oleh masuknya kelima variabel dalam model.

Pada model regresi variabel tangible paling berpengaruh terhadap kepuasan siswa terhadap layanan sekolah, oleh sebab itu variabel tangible (X5) adalah variabel yang lebih ditingkatkan dibandingkan variabel reliability (X1), responsiveness (X2), assurance (X3), empathy (X4)

\section{DAFTAR PUSTAKA}

Arikunto, Suharsimi. 2013.Prosedur Penelitian. Rineka Cipta: Jakarta

Azwar, S. 2002. Sikap Manusia Teori dan Pengukurannya. Pustaka Pelajar: Yogyakarta

Draper, N.R. dan Smith, H., (1992), Analisis Regresi Terjemahan Edisi Kedua, Gramedia, Jakarta.

Ghozali, Imam. 2001. Aplikasi Analisis Multivariat dengan program SPSS. Badan Penerbit Universitas Diponegoro: Semarang

Ghozali, Imam. 2005. Aplikasi Analisis Multivariat dengan program SPSS. Badan Penerbit Universitas Diponegoro: Semarang

Gujarati, D. 2009. Ekonometrika Dasar. Erlangga: Jakarta

Kotler, Philip. 1997. Manajemen Pemasaran. Analisis Perencanaan. Implementasi dan Kontrol, Jilid I, PT Prehalindo: Jakarta

Malhotra, Naresh, K. 2002. Marketing Research. Prantice Hall International Edirions: New Jersey

Moenir. 1998. Manajemen Pelayanan Umum Indonesia. Bumi Aksara: Jakarta

Pasuraman, A. Zeithalms, V. Berry, L. 1998. SERVQUAL: Multiple Item Scale for Measuring Customer Perceptions of Service Quality. Journal of Retailing. Vol. 64 No. 1 pp 29-40

Prianto, Agus. 2011. Faktor-faktor yang Mempengaruhi Kepuasan Orang Tua Siswa 
terhadap Layanan Pendidikan di Sekolah. STKIP PGRI Jombang: 2011

Retno, Dewi. 2010. Analisis Pengaruh Tingkat Kualitas Pelayanan Jasa Puskesmas Terhadap Kepuasan Pasien. Universitas Diponegoro: Semarang

Supranto, J. 1997. Pengukuran Tingkat Kepuasan Pelanggan untuk Menaikkan Pangsa Pasar. Rineka Cipta: Jakarta

Usman, Husaini.2006. Pengantar Statistika. Bumi Aksara: Yogyakarta
Walpole, E. Ronald. 1995. Pengantar Statistika, Edisi ketiga. PT. Gramedia Pustaka Utama: Jakarta.

http://taufikhasbi.blogspot.com/2011/05/contohkuesioner-penelitiansurvei.html diakses tanggal 15 April 2015

http://www.spssindonesia.com/2014/02/analisisregresi-multipes-denganspss.html diakses pada tanggal 20 April 2015 